\title{
Effect of Osmotic Shock and Shearing Forces on Ferric Enterochelin Transport in Escherichia coli K12
}

\author{
By DAVINDER S. PLAHA AND HENRY J. ROGERS* \\ National Institute for Medical Research, Mill Hill, London NW7 IAA, UK
}

(Received 24 August 1986; revised 18 November 1986)

The fes mutation in Escherichia coli $\mathrm{K} 12$, which inactivates enterochelin esterase, allows the cell to accumulate ferric enterochelin. The ferric complex of enterochelin was released in significant quantities from a fes mutant after osmotic shock. Analysis of the effects of the individual stages of the shock procedure in wild-type cells showed that prior exposure of cells to sucrose and EDTA was not required, careful dilution of cells into a hypo-osmolar medium being sufficient to induce efflux of $\mathrm{Fe}^{3+}$. Prior treatment with EDTA or exposure to shearing forces served either to enhance efflux or to induce efflux in isotonic media. Neither vitamin $B_{12}$ nor 5'-nucleotidase was released from the periplasm by these procedures. The release observed under mild conditions was stimulated specifically by $\mathrm{Co}^{2+}$, did not occur at $0^{\circ} \mathrm{C}$, and was inhibited by 2,4-dinitrophenol at $37^{\circ} \mathrm{C}$. From these observations, it was concluded that the efflux of $\mathrm{Fe}^{3+}$ represents a physiological response of the cell to exposure to a hypo-osmolar medium. Such changes may enhance survival following physicochemical stressing of the bacterial outer membrane.

\section{INTRODUCTION}

Iron deficiency in Escherichia coli arises after growth either in media containing submicromolar concentrations of iron or in body fluids such as serum or milk. In the latter, iron is present as stable complexes with the iron-binding proteins transferrin and lactoferrin. In each case, the ferric enterochelin transport system is induced in the bacterium (Braun, 1985; Rogers, 1983). Enterochelin, the cyclic trilactone of 2,3-dihydroxy- $N$-benzoyl-L-serine, is secreted into the medium (O'Brien \& Gibson, 1979; Rogers, 1973) where, by virtue of its extremely high affinity for $\mathrm{Fe}^{3+}$, the $\mathrm{Fe}^{3+}$ complex is formed by exchange reactions with $\mathrm{Fe}^{3+}$ complexes present in the medium (Carrano \& Raymond, 1979). The complex so formed is first adsorbed by a specific receptor (Fiss et al., 1982), the fepA gene product (Pierce et al., 1983), located in the bacterial outer membrane. The complex is then internalized by a process involving the ton $B$ function (Kadner \& McElhaney, 1978). The next stage of the process is not clearly understood but the $f e p B$ gene product may serve as a receptor for the complex on the cytoplasmic membrane (Pierce et al., 1983). Wild-type strains of $E$. coli possess an enterochelin esterase which degrades the lactone ring of the complex (Greenwood \& Luke, 1978) and may be involved in making iron available for incorporation into, for example, haem (Porra et al., 1972).

For some time we have been interested in the antibacterial effects of the indium and scandium complexes of enterochelin (Rogers et al., 1980, 1982). During the course of a detailed study of the mechanism of action of these compounds (Plaha \& Rogers, 1983; Plaha et al., 1984) it was found that a fes mutant, which lacks enterochelin esterase, tended to lose label spontaneously after incubation for $30 \mathrm{~min}$ or longer with either ${ }^{59} \mathrm{Fe}^{3+}$-enterochelin or ${ }^{46} \mathrm{Sc}^{3+}$-enterochelin. No such loss was observed from wild-type cells. The fes mutant accumulates considerable quantities of intact $\mathrm{Fe}^{3+}$ complex, as shown by the pink colour of cells exposed to $\mathrm{Fe}^{3+}$-enterochelin. The

Abbreviation: DNP, 2,4-dinitrophenol. 
transport system for vitamin $\mathbf{B}_{12}$ bears a number of similarities to that of ferric enterochelin, namely the presence of specific outer- and cytoplasmic-membrane receptors and the involvement of the $\operatorname{ton} B$ function. On subjecting $E$ : coli to osmotic shock (suspension in sucrose/EDTA followed by dilution), both vitamin $B_{12}$ (Reynolds et al., 1980) and a number of enzymes (Nossal \& Heppel, 1966) are rapidly released from the periplasmic space. In view of these findings it was decided to employ the osmotic shock technique in an attempt to determine the site of accumulation of ferric enterochelin.

\section{METHODS}

Chemicals. All chemicals used were of analytical grade. ${ }^{59} \mathrm{FeCl}_{3},\left[{ }^{57} \mathrm{Co}\right.$ cyanocobalamin (vitamin $\mathrm{B}_{12}$ ) and [U$\left.{ }^{14} \mathrm{C}\right]$ protein hydrolysate were obtained from Amersham. The preparation of $\left[{ }^{14} \mathrm{C}\right]$ enterochelin was described earlier (Plaha \& Rogers, 1983).

Bacteria. The two E. coli K12 strains used were the wild-type HfrH thi and AN273 fes (Porra et al., 1972). Irondeficient bacteria were used throughout. They were obtained by growing the cells in the presence of conalbumin (Sigma), $0.5 \mathrm{mg} \mathrm{ml}^{-1}$, in either trypticase soy broth or medium 56 (Monod et al., 1951) containing appropriate supplements (Porra et al., 1972) (medium A).

Preparation and measurement of uptake of ${ }^{59} \mathrm{Fe}^{3+}$-enterochelin and $\mathrm{Fe}^{3+}-\left[{ }^{14} \mathrm{C}\right]$ enterochelin. These procedures have been described previously (Plaha \& Rogers, 1983). All radioactive samples were counted in duplicate. The experimental results have been checked for reproducibility; the use of early exponential phase cultures appeared to be particularly important in this respect.

Uptake of $\left[{ }^{57}\right.$ Co]vitamin $B_{12}$. After addition of $\left[{ }^{57} \mathrm{Co}\right]$ vitamin $\mathrm{B}_{12}$ at a concentration of $10 \mathrm{nM}$ to cells at $37^{\circ} \mathrm{C}$, uptake of the label was determined as for the uptake of enterochelin complexes. Membrane filters were soaked before use for $30 \mathrm{~min}$ in $10 \mu \mathrm{M}$-vitamin $\mathrm{B}_{12}$ solution and finally washed three times in distilled water.

The counting efficiency of ${ }^{57} \mathrm{Co}$ was $90 \%$ and the specific activity was $7.14 \mu \mathrm{Ci}_{\mu \mathrm{g}}{ }^{-1}\left(264.2 \mathrm{kBq} \mu \mathrm{g}^{-1}\right)$.

Osmotic shock treatment. After uptake of the labelled complexes of enterochelin had proceeded to $20-60 \mathrm{~min}$, the cells were subjected to osmotic shock (Reynolds et al., 1980). Basically, this involved addition of solid sucrose to the culture to give a concentration of $10 \%(\mathrm{w} / \mathrm{v})$, followed, after $5 \mathrm{~min}$, by $2 \mathrm{mM}$-EDTA and then immediate dilution of $0.1 \mathrm{ml}$ (obtained with a Gilson P200 micropipette fitted with a C20 tip) of the culture into $10 \mathrm{ml}$ distilled water at $37^{\circ} \mathrm{C}$. In some experiments, bacteria were collected by centrifugation and then subjected to osmotic shock at $4^{\circ} \mathrm{C}$ (Nossal \& Heppel, 1966). Duplicate samples $(0.5 \mathrm{ml})$ were removed during the uptake phase and immediately before the application of osmotic shock. Samples $(1 \mathrm{ml})$ of the shocked cell suspension were also removed at intervals over a $30 \mathrm{~min}$ incubation period at $37^{\circ} \mathrm{C}$. The cells were collected on membrane filters $(0.45 \mu \mathrm{m})$ and washed with $1 \mathrm{ml}$ saline $(0.85 \% \mathrm{NaCl})$ or $10 \%(\mathrm{v} / \mathrm{v})$ TSB in $0.85 \% \mathrm{NaCl}$ (broth saline) (depending on whether the uptake was in medium A or TSB). Radioactive counting of dried membranes in toluene scintillation fluid was used to measure the amount of label associated with the cells (Plaha \& Rogers, 1983).

Effect of EDTA and dilution. After a $30 \mathrm{~min}$ period of uptake of the complex, $2 \mathrm{mM}$-EDTA was added to the culture and samples were diluted 100 -fold at $37^{\circ} \mathrm{C}$. Loss of label from the cells was determined as described above.

$5^{5}$-Nucleotidase assay. After growing bacteria in the appropriate medium, $5 \times 10^{8}$ cells suspended in $5.0 \mathrm{ml}$ $0.85 \% \mathrm{NaCl}$ were subjected to either osmotic shock, sonication $(12 \times 10 \mathrm{~s} ;$ MSE $100 \mathrm{~W}$ ultrasonic disintegrator), treatment with EDTA followed by dilution, or dilution alone. Each treatment was followed immediately by membrane filtration $(0.45 \mu \mathrm{m})$. The filtrates were assayed according to Sigma Technical Bulletin no. 675 except that $0.01 \mathrm{M}-\mathrm{CaCl}_{2}$ and $\mathrm{CoCl}_{2}$ were added for optimum activity (Neu \& Heppel, 1965).

Gel electrophoresis of membrane proteins after osmotic shock. The fes mutant was grown to the exponential phase in medium A (Plaha \& Rogers, 1983) supplemented with $0.25 \mu \mathrm{Ci} \mathrm{ml}^{-1}{ }^{14} \mathrm{C}$-labelled amino acids $[57 \mathrm{mCi}$ (2.1 MBq) per milliatom carbon]. To a $10 \mathrm{ml}$ cell suspension $\left(2 \times 10^{8}\right.$ cells ml$\left.^{-1}\right)$ was added $\mathrm{Fe}^{3+}$-enterochelin (final concn $1 \mu \mathrm{M}$ ), and the culture was stirred at $37^{\circ} \mathrm{C}$ for $20 \mathrm{~min}$. EDTA $(2 \mathrm{mM})$ was then added and the cells were immediately harvested by centrifugation in the cold $(12000 \mathrm{~g}$ for 2-3 $\mathrm{min})$. A control sample containing no EDTA was also prepared. The bacterial pellets were resuspended in distilled water at $37^{\circ} \mathrm{C}$ and incubation was continued with shaking for $\mathrm{l} \mathrm{h}$. The cells were then harvested as above and finally resuspended in $2 \mathrm{ml} 0.01 \mathrm{M}$-Tris/ $/ \mathrm{HCl}$, pH 8.5, containing $2 \mathrm{mM}-E D T A$ and to this was added $3 \mathrm{ml}$ of unlabelled carrier cells $\left(2 \times 10^{9} \mathrm{ml}^{-1}\right)$ in the same buffer. Bacterial outer membranes were obtained as the insoluble fraction after treatment of the cells with $0.5 \%$ Sarkosyl NL97 (Lugtenberg et al., 1975). The supernatants obtained after centrifugation of cells incubated in distilled water were membrane filtered $(0.45 \mu \mathrm{m})$ and freeze-dried in $2 \mathrm{ml}$ volumes. These were reconstituted in $0.2 \mathrm{ml}$ of non-radioactive outer-membrane protein preparations in $0.0625 \mathrm{M}-\mathrm{Tris} / \mathrm{HCl}, \mathrm{pH} \mathrm{6.8}$, containing appropriate supplements for application to gels (Lugtenberg et al., 1975). After SDS polyacrylamide gel electrophoresis, staining was done with $0.25 \%$ Coomassie blue in methanol. Gels were dried on Whatman $3 \mathrm{MM}$ paper prior to autoradiography. The authoradiographs were developed after one week. 
RESULTS

\section{Release of label after osmotic shock}

After uptake of ${ }^{59} \mathrm{Fe}^{3+}$-enterochelin by wild-type $E$. coli $\mathrm{K} 12$ from a $1 \mu \mathrm{M}$ solution in TSB for $60 \mathrm{~min}$, cells were subjected to sucrose/EDTA treatment and the suspension was diluted 100fold into water by micropipette. This osmotic shock resulted in $25 \%$ loss of label from the cells over a period of $30 \mathrm{~min}$. When the salts medium A (Plaha \& Rogers 1983) was used rather than TSB as suspending medium, $17 \%$ of the label was lost from the cells. Corresponding representative figures for the fes mutant were $11 \%$ and $59 \%$ respectively. The results obtained using medium $A$ are in accord with the idea that in this mutant, the intact complex accumulates within the bacterial cell (Greenwood \& Luke 1978) whilst the relatively low figure obtained with TSB is in accord with previous observations that $\mathrm{Fe}^{3+}$-enterochelin is degraded, to some extent, by this mutant suspended in a rich medium (Plaha \& Rogers 1983). It should be noted that with the fes mutant in medium $\mathrm{A}$, a significant proportion (17\%) of the label was lost spontaneously after $30 \mathrm{~min}$ of uptake and well before the application of osmotic shock at $60 \mathrm{~min}$. When the cells were shocked after a 20 min uptake period, a larger amount $(38 \%)$ of the label was lost.

It was observed in each of three experiments that when cells were treated with sucrose/EDTA, collected by centrifugation and resuspended in diluting fluid at $4{ }^{\circ} \mathrm{C}$ as described by Nossal \& Heppel (1966), little or no loss of label occurred. On raising the temperature to $37^{\circ} \mathrm{C}$, however, label was lost from the cells, although the loss was only half that detected following micropipetting and dilution of the culture. The rate of release of $\mathrm{Fe}^{3+}$ enterochelin observed in these experiments is slow compared to that of either vitamin $\mathbf{B}_{12}$ (Reynolds et al., 1980) or certain periplasmic enzymes (Nossal \& Heppel, 1966), where equilibration with the medium is almost complete within 1-2 min.

As a control for the osmotic shock technique, the supernatant was assayed for the presence of 5 '-nucleotidase, one of several enzymes released by subjecting the cells to osmotic shock (Nossal \& Heppel, 1966). When represented as a percentage of the maximum amount of enzyme released after sonication, the release of 5'-nucleotidase following osmotic shock of $E$. coli $\mathrm{K} 12$ wild-type and $f e s$ cells was $36 \%$ and $32 \%$ respectively (data not shown). These values agree fairly well with the figure of $46 \%$ given by Nossal \& Heppel (1966).

\section{Release of label after addition of EDTA followed by dilution}

The unexpectedly slow release of label after osmotic shock prompted an examination of the effect of each stage of the procedure. Addition of 2 mM-EDTA followed by a 100 -fold dilution by micropipetting into distilled water at $37^{\circ} \mathrm{C}$ after uptake of iron from $1 \mu \mathrm{M}-{ }^{59} \mathrm{Fe}^{3+}$-enterochelin by wild-type E. coli $\mathrm{K} 12$ in TSB or $E$. colifes in medium A resulted in $18 \%$ and $50 \%$ release of the label respectively. These values are similar to those obtained when the bacteria were subjected to the complete osmotic shock procedure which requires the initial addition of $10 \%$ sucrose. Changing the diluting medium from distilled water to $0.85 \% \mathrm{NaCl}$ or TSB (the uptake medium) made little difference to the release of label from wild-type $E$. coli $\mathrm{K} 12(14 \%$ and $12 \%$ respectively). However, dilution into TSB containing $2 \mathrm{~mm}$-EDTA resulted in no release, although dilution into either aqueous EDTA alone or $4 \mathrm{~mm}$-2,4-dinitrophenol (DNP) did not significantly inhibit the release of radioactivity from cells $(21 \%$ and $11 \%$ respectively). The $35 \%$ release of label from $E$. coli fes after dilution into the same medium as that used for the uptake (medium A) was slightly less than that after dilution into distilled water $(50 \%)$.

In order to differentiate between the release of iron and that of the $\mathrm{Fe}^{3+}$-enterochelin complex, E. coli fes was allowed to accumulate label from $1 \mu \mathrm{M}-\mathrm{Fe}^{3-}-\left[{ }^{14} \mathrm{C}\right]$ enterochelin in medium A, after which 2 mM-EDTA was added and the cells were harvested by centrifugation and resuspended in distilled water at $37{ }^{\circ} \mathrm{C}$. There was $21 \%$ release of label after incubation for $30 \mathrm{~min}$. The same treatment during uptake of label from $1 \mu \mathrm{M}^{-59} \mathrm{Fe}^{3+}$-enterochelin released $24 \%$ of the accumulated label, suggesting that the intact ferric enterochelin complex is released from the mutant. Since the specific activity of the $\left[{ }^{14} \mathrm{C}\right]$ enterochelin was low, the technique of Nossal \& Heppel (1966), which involves centrifugation followed by resuspension of the pellet, was used in this case. 
Table 1. Effect of cations on the release of ${ }^{59} \mathrm{Fe}^{3+}$-enterochelin from $\mathrm{E}$. coli $\mathrm{K} 12$

\begin{tabular}{|c|c|c|}
\hline \multirow[b]{2}{*}{ Cation } & \multicolumn{2}{|c|}{ Radioactivity released $(\%)^{*}$} \\
\hline & Wild-type ${ }^{\prime}$ & fes mutant $\ddagger$ \\
\hline None (control) & 18 & 50 \\
\hline $\mathrm{Fe}^{3+}$ & 15 & 50 \\
\hline $\mathrm{Zn}^{2+}$ & 13 & 51 \\
\hline $\mathrm{Mn}^{2+}$ & 21 & 57 \\
\hline $\mathrm{Mg}^{2+}$ & 22 & - \\
\hline $\operatorname{In}^{3+}$ & 15 & 61 \\
\hline $\mathrm{Cd}^{2+}$ & 17 & - \\
\hline $\mathrm{Co}^{2+}$ & 45 & 60 \\
\hline
\end{tabular}

* Percentage radioactivity released at $37^{\circ} \mathrm{C} 30 \mathrm{~min}$ after the addition of $2 \mathrm{~mm}$-EDTA and immediate dilution of $0.1 \mathrm{ml}$ into $10 \mathrm{ml} 40 \mu \mathrm{M}$-cation solution in water $\left(100 \%\right.$ represents not less than $2 \times 10^{3}$ c.p.m. per $10^{8}$ cells). + After $60 \mathrm{~min}$ uptake in TSB.

$\ddagger$ After 20 min uptake in medium A.

Control experiments showed that addition of 2 mM-EDTA to $E$. coli fes followed by 100 -fold dilution by micropipetting into distilled water at $37^{\circ} \mathrm{C}$ did not cause any release of periplasmic 5 '-nucleotidase. Likewise, this treatment caused no release of label from $E$. coli fes during uptake of $10 \mathrm{nM}-\left[{ }^{57} \mathrm{Co}\right] v i t a m i n B_{12}$ in medium $A$ (data not shown). It seemed possible, therefore, that either a significant proportion of the $\mathrm{Fe}^{3+}$-enterochelin may have been released from the outermembrane receptor or that the receptor itself was lost from the cells (Pugsley \& Reeves, 19?7). However, treatment of $E$. coli fes labelled with ${ }^{14} \mathrm{C}$-labelled amino acids with 2 mM-EDTA followed by resuspension in distilled water at $37^{\circ} \mathrm{C}$ did not appear to release either the outermembrane receptor for ferric enterochelin or any other proteins of $M_{\mathrm{r}}>32000$, as determined by SDS polyacrylamide gel electrophoresis of the outer-membrane proteins and the supernatant (Lugtenberg et al., 1975) (data not shown).

\section{Effect of cations on the release of label}

The results presented above suggested that the release of label from cells after addition of EDTA followed by dilution was not solely a consequence of osmotic difference between the uptake and the diluting medium. In particular, the prevention of release into TSB by the presence of EDTA suggested that some cation present in the broth may have been aiding the release of label. This possibility was examined by supplementing the diluting medium with various cations. Table 1 illustrates their effect on the release of label after addition of EDTA and dilution by micropipetting during uptake of iron from $1 \mu \mathrm{M}^{-59} \mathrm{Fe}^{3+}$-enterochelin by $E$. coli $\mathrm{K} 12$ in TSB and $E$. coli fes in medium A. The cations were present at twice the final concentrations of EDTA. Of all the ions tested, only $\mathrm{Co}^{2+}(40 \mu \mathrm{M})$ had a marked stimulatory effect on the release of label from wild-type cells; this effect was observed consistently in five experiments. None of the ions tested had a significant effect on the release of label from the fes mutant. The loss of label from wild-type cells after dilution into the $\mathrm{Co}^{2+}$ solution was reduced by the presence in the solution of either $2 \mathrm{~mm}$-EDTA or $4 \mathrm{mM}$-DNP (Fig. 1), suggesting that the release is specifically related to the $\mathrm{Co}^{2+}$ ion and requires an energized cytoplasmic membrane.

\section{Effect of shearing forces on the release of label}

Comparison of the results obtained by dilution using a micropipette with those obtained by centrifugation and resuspension (Nossal \& Heppel, 1966) showed consistently that more label was released by the first of these techniques. It was considered that shearing forces may have been responsible for this difference. Further, since EDTA actualy inhibited the subsequent loss of label from cells after dilution into TSB, it was decided to omit this reagent. The release of radioactivity following a 100 -fold dilution into various solutions at $37^{\circ} \mathrm{C}$ during uptake of iron from $1 \mu \mathrm{M}-\mathrm{Fe}^{3+}$-enterochelin by wild-type $E$. coli $\mathrm{K} 12$ in TSB is illustrated in Fig. 2 . The dilutions were made either by adding a $0.1 \mathrm{ml}$ sample by micropipette to $10 \mathrm{ml}$ medium (method 


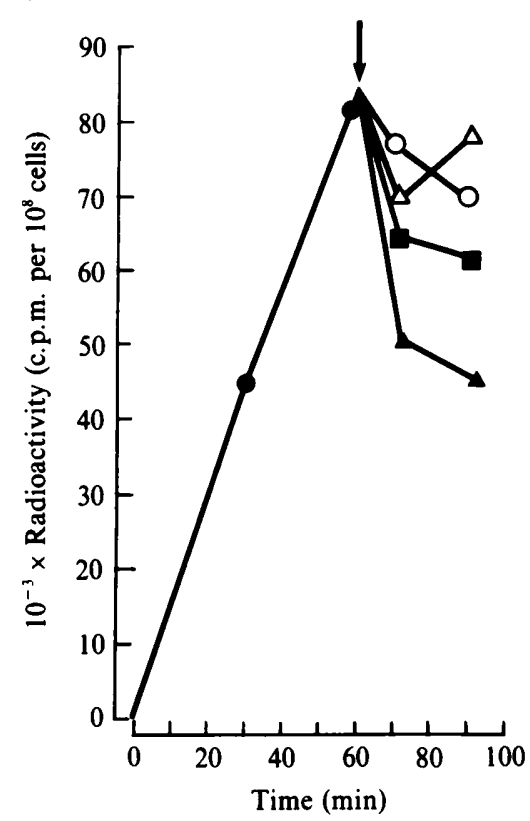

Fig. 1

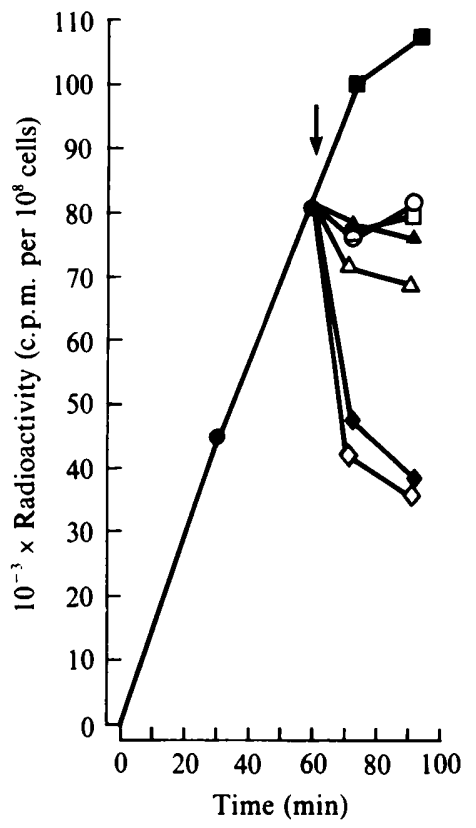

Fig. 2

Fig. 1. Effect of dilution on $\mathrm{Fe}^{3+}$-enterochelin transport in wild-type $E$. coli $\mathrm{K} 12$ suspended in $1 \mu \mathrm{M}$ ${ }^{59} \mathrm{Fe}^{3+}$-enterochelin in TSB (specific activity of ${ }^{59} \mathrm{Fe}^{3+} 13 \cdot 3 \mu \mathrm{Ci} \mu \mathrm{g}^{-1}$ ). $O$, Uptake phase; at $60 \mathrm{~min}$ (arrow) $2 \mathrm{mM}$-EDTA was added and $0.1 \mathrm{ml}$ samples were diluted into $10 \mathrm{ml}$ of: water $(\mathrm{O}), 40 \mu \mathrm{M}-\mathrm{CoCl}_{2}$ $(\triangle), 40 \mu \mathrm{M}-\mathrm{CoCl}_{2}+4 \mathrm{mM}-\mathrm{DNP}(\triangle)$, or $40 \mu \mathrm{M}-\mathrm{CoCl}_{2}+2 \mathrm{mM}-\mathrm{EDTA}(\square)$ (all maintained at $37^{\circ} \mathrm{C}$ ).

Fig. 2. Effect of dilution technique on $\mathrm{Fe}^{3+}$-enterochelin transport in wild-type $E$. coli $\mathrm{K} 12$ suspended in $1 \mu \mathrm{M}-{ }^{59} \mathrm{Fe}^{3+}$-enterochelin in TSB (specific activity of ${ }^{59} \mathrm{Fe}^{3+} 13.3 \mu \mathrm{Ci} \mu \mathrm{g}^{-1}$ ). $\mathrm{O}$, Uptake phase; at 60 min (arrow) samples were diluted 100-fold into TSB $(O)$, water $(\triangle, \triangle), 0.85 \% \mathrm{NaCl},(\square, \square)$, or $20 \mu \mathrm{M}-\mathrm{CoCl}_{2}(\diamond, \diamond)$. Open symbols refer to $0.1 \mathrm{ml}$ samples diluted by micropipette into $10 \mathrm{ml}$ diluent (method A); filled symbols refer to $100 \mathrm{ml}$ diluent added carefully to $1.0 \mathrm{ml}$ culture (method B).

A) or by a gentle addition of $100 \mathrm{ml}$ medium to a $1 \mathrm{ml}$ sample (method B). When TSB and saline were used as diluting media, there was no release of label by method A, although further uptake of ferric enterochelin was inhibited. However, dilution into saline by method B caused neither release of label nor inhibition of its uptake. By comparison with the results described above, it appears that release into saline or TSB requires prior treatment of cells with EDTA. Loss of radioactivity from cells after dilution into distilled water was greater using method $A$ than by method B, the release by method A being similar to that after osmotic shock or EDTA-dilution (Fig. 1). The results suggest that the release of $\mathrm{Fe}^{3+}$ is partly due to the osmotic difference between the uptake and the diluting medium and partly a result of shearing during pipetting. However, the effect of pipetting is not important in the release of label when the diluting medium is supplemented with $20 \mu \mathrm{M}-\mathrm{Co}^{2+}$, since in this case the loss of radioactivity from the cells was the same whether the dilutions were made according to method A or B (Fig. 2). The release of label was large and similar to that resulting from addition of EDTA followed by dilution into $\mathrm{Co}^{2+}$ solution. Dilution by method A into TSB supplemented with $20 \mu \mathrm{M}-\mathrm{CoCl}_{2}$ resulted in no release of label (data not shown), suggesting that the enhancement of release by $\mathrm{Co}^{2+}$ occurs only in a hypo-osmotic medium.

Control experiments showed that dilution by method $\mathrm{A}$ into $20 \mu \mathrm{M}-\mathrm{Co}^{2+}$ solution caused no significant release of periplasmic 5'-nucleotidase from wild-type $E$. coli $\mathrm{K} 12$. Similarly, dilution into distilled water, $0.85 \%$ saline or $20 \mu \mathrm{M}-\mathrm{Co}^{2+}$ solution during uptake of $10 \mathrm{nM}-\left[{ }^{57} \mathrm{Co}\right]$ vitamin $B_{12}$ by wild-type cells in TSB did not result in any significant loss of radioactivity from the cells (data not shown). It was concluded that the release of $\mathrm{Fe}^{3+}$ following dilution into $\mathrm{Co}^{2+}$ solution appears to be a specific effect. 


\section{DISCUSSION}

Recently published work has shown that $E$. coli can accumulate a pool of $\mathrm{Fe}^{3+}$-enterochelin. This appears to be present in the periplasmic space since it undergoes exchange with extracellular complex and is released from the cell following osmotic shock (Ecker et al., 1986; Matzanke et al., 1986). We began our work using a fes mutant of E. coli K12 in which the lack of enterochelin esterase allows the cell to accumulate $\mathrm{Fe}^{3+}$-enterochelin. The site of this accumulation was examined by the application of osmotic shock. The ferric complex of enterochelin was released in significant quantities from the mutant. Analysis of the effects of the individual stages of the shock procedure on wild-type cells showed that prior exposure of cells to sucrose and EDTA was not required, careful dilution of cells into a hypo-osmolar medium being sufficient to induce efflux of $\mathrm{Fe}^{3+}$. Prior treatment with EDTA or exposure to shearing forces served either to enhance efflux or to induce efflux in isotonic media. Efflux was temperature dependent. Control experiments showed that neither vitamin $\mathbf{B}_{12}$ nor $5^{\prime}$-nucleotidase was released from the periplasm by these procedures. The release of $\mathrm{Fe}^{3+}$ from wild-type cells under mild conditions was stimulated specifically by $\mathrm{Co}^{2+}$, but $\mathrm{Co}^{2+}$ did not stimulate the release of $\mathrm{Fe}^{3+}$-enterochelin from the mutant. The observation (Fig. 1) that efflux in the presence of $\mathrm{Co}^{2+}$ was abolished by DNP suggested that in this case the release is an active process, dependent upon the proton-motive force, rather than passive diffusion. Shearing forces encountered during micropipetting enhanced release of $\mathrm{Fe}^{3+}$ from the cells but failed to release either $\left[{ }^{57} \mathrm{Co}\right]$ vitamin $B_{12}$ (Reynolds et al., 1980) or 5'-nucleotidase (Nossal \& Heppel, 1966), both well-characterized markers of the periplasm. Thus, the release of ${ }^{59} \mathrm{Fe}^{3+}$ could have arisen through the combined action of shearing forces and a physiological response to a hypo-osmolar medium. The mildest conditions giving maximal release consisted of careful dilution into water containing $20 \mu \mathrm{M}$ $\mathrm{Co}^{2+}$.

It is necessary to form a working hypothesis based on these observations. Clearly, osmotic shock in the accepted sense (Neu \& Heppel, 1965; Nossal \& Heppel, 1966) is not involved. Further, the effect of shearing forces introduces a complication but even so it is interesting that these forces immediately inhibit uptake of $\mathrm{Fe}^{3+}$-enterochelin (Fig. 1), presumably as a result of the loss or disorganization of some outer-membrane component. However, these shearing forces only induce an actual loss of label from cells previously exposed to EDTA. It seems possible therefore that the efflux which occurs on careful dilution into a hypo-osmolar medium could be a normal physiological response to a shift down to a dilute medium. The effects of exposing $E$. coli to hyperosmotic solutions have been studied quite thoroughly (LeRudulier et al., 1984). From the present work, the response to hypo-osmolarity appears to be quite rapid (Figs 1 and 2), and thus may be under the control of an allosteric effector which responds to the osmolarity of the medium. The fact that the efflux is driven by an energized membrane also suggests that it is a physiological response. $\mathrm{Co}^{2+}$ appears to be an essential cofactor for the release of $\mathrm{Fe}^{3+}$ from the cell.

The consequences of the loss of $\mathrm{Fe}^{3+}$-enterochelin on the physiology of the cell must be considered. As iron-deficient cells were used throughout this work, the efflux of either $\mathrm{Fe}^{3+}$. enterochelin or $\mathrm{Fe}^{3+}$ seems to represent the loss of a short-term storage form of iron. This loss implies an enhancement of iron deficiency on exposure to a hypo-osmolar, and in the present context, nutritionally poor medium. Although iron-deficient bacteria are known to lack a number of enzymes for which iron is an essential cofactor (Coughlan, 1971), the rapid response encountered here implies the presence of an active control system rather than passive dilution of iron during repeated cell division cycles. Such systems have been described by Buck \& Griffiths (1982), who found both increased expression of the trp operon and enhanced transport of aromatic amino acids due to the presence of undermodified tRNAs in iron-deficient $E$. coli (Buck \& Griffiths, 1981). The phenotypic changes in iron metabolism which occur on exposure of enterobacterial pathogens to body fluids (Griffiths et al., 1983; Rogers, 1973) point to a central role for iron metabolism in bacterial survival under adverse conditions. The present results also suggest an adjustment in iron metabolism which may enable the organism to survive under hypo-osmolar conditions. It is known, for example, that Salmonella typhi can survive in small numbers for at least two weeks at ambient temperature in river water (Wilson, 1983). 
Boyd \& Holland (1977) showed that simple filtration and resuspension of $E$. coli $\mathrm{K} 12$ can induce the synthesis of the outer-membrane receptor for $\mathrm{Fe}^{3+}$-enterochelin. This observation, together with those presented above on the effect of shearing, suggest that the physical stressing of the outer membrane of $E$. coli leads to rapid and marked changes in the $\mathrm{Fe}^{3+}$-enterochelin transport system.

Bacterial iron metabolism is known to be an important determinant of virulence. It may be that exposure of cells to shearing forces during the process of injection into experimental animals may result in a temporary change in virulence. Such an effect would represent yet another complication when comparing in vitro- and in vivo-grown bacteria (Penn et al., 1976).

\section{REFERENCES}

Boyd, A. \& Holland, I. B. (1977). Protein D, an irontransport protein induced by filtration of cultures of Escherichia coli. FEBS Letters 76, 20-24.

BraUN, V. (1985). The unusual features of the iron transport systems of Escherichia coli. Trends in Biochemical Sciences 10, 75-78.

BUCK, M. \& GRIFFITHS, E. (1981). Regulation of aromatic amino acid transport by tRNA; role of 2 methylthio- $N^{6}-\left(\Delta^{2}\right.$-isopentenyl)-adenosine. Nucleic Acids Research 9, 401-414.

BUCK, M. \& GRIFFITHS, E. (1982). Iron mediated methylthiolation of tRNA as a regulator of operon expression in Escherichia coli. Nucleic Acids Research 10, 2609-2624.

Carrano, C. J. \& Raymond, K. N. (1979). Ferric iron sequestering agents. 2. Kinetics and mechanism of iron removal from transferrin by enterochelin and synthetic tricatechols. Journal of the American Chemical Society 101, 5401-5404.

Coughlan, M. P. (1971). The role of iron in microbial metabolism. Science Progress 59, 1-23.

ECKeR, D. J., Matzanke, B. F. \& Raymond, K. N. (1986). Recognition and transport of ferric enterobactin in Escherichia coli. Journal of Bacteriology 167, 666-673.

Fiss, E. H., Stanley-Samuelson, P. \& Neilands, J. B. (1982). Properties and proteolysis of ferric enterobactin outer membrane receptor in Escherichia coli K12. Biochemistry 21, 4517-4522.

GREeNWOOD, K. T. \& LUKE, R. K. J. (1978). Enzymatic hydrolysis of enterochelin and its iron complex in Escherichia coli K12. Biochimica et biophysica acta 528, 209-218.

Griffiths, E., Stevenson, P. \& Joyce, P. (1983). Pathogenic Escherichia coli express new outer membrane proteins when growing in vivo. FEMS Microbiology Letters 16, 95-99.

KADNER, R. J. \& McElhaney, G. (1978). Outer membrane dependent transport systems in Escherichia coli: turnover of tonB function. Journal of Bacteriology 134, 1020-1029.

LeRudulier, D., Strom, A. R., Dandeliar, A. M., SMith, L. T. \& VAlentine, R. C. (1984). Molecular biology of osmoregulation. Science 224, 1064-1068.

Lugtenberg, B., Meijers, J., Peters, R., Van Der HoEl, P. \& VAN AlPhen, L. (1975). Electrophoretic resolution of the major outer membrane proteins of Escherichia coli $\mathrm{K} 12$ into four bands. FEBS Letters 58, 254-258.

MATZANKe, B. F., Ecker, D. J., YANG, T.-S., HuYnh, B. H., Muller, G. \& Raymond, K. N. (1986).
Escherichia coli iron enterobactin uptake monitored by Mossbauer spectroscopy. Journal of Bacteriology 167, 674-680.

Monod, J., Cohen-Bazire, G. \& Cohen, M. (1951). Sur la biosynthese de la $\beta$-galactosidase (lactase) chez Escherichia coli. La spécificité de l'induction. Biochimica et biophysica acta 7, 585-599.

NEU, H. C. \& HEPPEL, L. A. (1965). The release of enzymes from Escherichia coli by osmotic shock during the formation of spheroblasts. Journal of Biological Chemistry 240, 3685-3692.

Nossal, N. G. \& Heppel, L. A. (1966). The release of enzymes by osmotic shock from Escherichia coli in exponential phase. Journal of Biological Chemistry 241, 3055-3062.

O'BriEN, I. G. \& Gibson, F. (1979). The structure of enterochelin and related 2,3-dihydroxy- $N$-benzoylserine conjugates from Escherichia coli. Biochimica et biophysica acta 215, 393-402.

Penn, C. W., Sen, D., Veale, D. R., Parsons, N. J. \& SMITH, H. (1976). Morphological, biological and antigenic properties of Neisseria gonorrhoeae adapted for growth in guinea pig subcutaneous chambers. Journal of Bacteriology 97, 35-43.

Pierce, J. R., Pickett, C. L. \& Earhart, C. F. (1983). Two fes genes are required for ferrienterochelin uptake in Escherichia coli K12. Journal of Bacteriology 155, 330-336.

Plaha, D. S. \& Rogers, H. J. (1983). Antibacterial effect of the scandium complex of enterochelin. Studies of the mechanism of action. Biochimica et biophysica acta 760, 246-255.

Plaha, D. S., Rogers, H. J. \& Williams, G. W. (1984). Studies of the antibacterial effect of the scandium complex of enterochelin. Journal of Antibiotics 37, 588-595.

Porra, R. J., Langman, L., Young, I. G. \& Gibson, F. (1972). The role of ferric enterochelin esterase in enterochelin mediated iron transport and ferrochelatase activity in Escherichia coli. Archives of Biochemistry and Biophysics 153, 74-78.

Pugsley, A. P. \& Reeves, P. (1977). Uptake of ferrienterochelin by Escherichia coli: energy dependent stage of uptake. Journal of Bacteriology 130, 2636.

Reynolds, P. R., Mottur, G. P. \& Bradbeer, C. (1980). Transport of vitamin $B_{12}$ in Escherichia coli. Journal of Biological Chemistry 255, 4313-4319.

Rogers, H. J. (1973). Iron binding catechols and virulence in Escherichia coli. Infection and Immunity 7, 445-456. 
ROGERS, H. J. (1983). Role of iron chelators, antibodies and iron binding proteins in infection. In Microbiology-1983, pp. 334-337. Edited by D. Schlessinger. Washington, DC: American Society for Microbiology.

Rogers, H. J., SYNGe, C. \& WoOds, V. E. (1980). Antibacterial effect of scandium and indium complexes of enterochelin on Klebsiella pneumoniae. Antimicrobial Agents and Chemotherapy 18, 63-68.
Rogers, H. J., Woods, V. E. \& Synge, C. (1982). Antibacterial effect of the scandium and indium complexes of enterochelin on Escherichia coli. Journal of General Microbiology 128, 2389-2394.

WILSON, G. (1983). The bacteriology of air, water and milk. In Topley and Wilson's Principles of Bacteriology, Virology and Immunity, 7th edn, vol. 1, p. 262. Edited by G. Wilson \& H. M. Dick. London: Edward Arnold. 